УДК 340.1

DOI https://doi.org/10.32837/apdp.v0i83.112

О.С. Бакумов

\title{
ЮРИДИЧНА ВІДПОВІДАЛЬНІСТЬ ЯК ЕЛЕМЕНТ ПРАВОВОГО СТАТУСУ ДЕРЖАВИ: ТЕОРЕТИКО-ПРАВОВІ АСПЕКТИ
}

Постановка проблеми. Тривалий час в юриспруденції інститут юридичної відповідальності розглядався як набуток та іманентна властивість індивідуальних та колективних суб'єктів права. При цьому зазвичай із понятійного ряду таких суб'єктів елімінувалася держава як специфічний суб'єкт права. Досить поширеними були (та навіть зараз $є$ ) концепції, що з різних позицій обгрунтовують абсолютний юридичний імунітет держави, по суті, вивищуючи їі над іншими суб'єктами права та виводячи її зі сфери юридичної відповідальності (втілюючи тим самим старий монархічний принцип, за яким король, себто держава, не може бути неправа), або замінюючи останню політичною чи моральною відповідальністю, або й узагалі заперечуючи будь-яку відповідальність держави як такої (підміняючи юридичну відповідальність держави відповідальністю державних службовців тощо). Між тим такі концептуальні побудови вочевидь розходяться як із теоріями правової держави, так і з практикою реалізації відповідального правління в багатьох зарубіжних державах, які дедалі щільніше «вмонтовуються» у систему відносин юридичної відповідальності [1]. При цьому такі відносини набувають як внутрішньодержавного, так і наднаціонального характеру (зокрема, через інститут міжнародно-правової відповідальності держав, який набуває дедалі більшого поширення).

Тим часом практична значущість дискурсу щодо юридичної відповідальності держави все частіше співвідноситься з тими проблемами, що їх зазначає в ході конституційної трансформації правовий статус власне Української держави. Зазвичай ця чільна для юриспруденції категорія розглядається відірвано від розуміння іманентної притаманності цьому статусові ознак юридичної відповідальності. Зрештою, і формалізований Конституцією України ще у 1996 році інститут юридичної відповідальності держави тривалий час не ставав елементом повсякденних практик функціонування державного апарату. У зв'язку із цим провідними вітчизняними вченими-правознавцями було слушно констатовано, що наявний новітній національний досвід «глибоко переконує в неефективності діяльності Української держави щодо розв'язання соціально-економічних проблем громадян, що нерідко призводить до значних соціально-політичних конфліктів, порушення конституційних прав людини. У цьому контексті йдеться про відповідальність держави за бездіяльність ї̈ органів та посадових осіб за грубі порушення конституційних прав громадян Української держави. Подібний стан речей безпосередньо породжує відчуття безкарності, вседозволеності значної частини державних чиновників і держави в цілому, що породжує зневіру населення до її владних структур. Однією з основних причин безвідповідальності держави за бездіяльність їі органів та інститутів є відсутність ефективних механізмів реалізації відповідальності держави перед собою. Саме тому першочерговим завданням всього українського суспільства

(C) О. С. Бакумов, 2019 
має стати створення ефективних механізмів реалізації відповідальності держави перед суспільством і людиною» [2, с. 80].

Одним із перспективних напрямів реалізації відповідних дослідницьких зусиль має стати аналіз ролі та місця юридичної відповідальності держави у структурі правового статусу держави з подальшим «виходом» теоретичних висновків у сферу предметних пропозицій щодо оптимізації конструкції як правового статусу Української держави загалом, так і такого базового елемента цієї конструкції, яким $\epsilon$ інститут юридичної відповідальності держави.

Аналіз наукових досліджень. Під час дослідження особливостей правового статусу держави та визначення місця в ньому юридичної відповідальності цього публічно-правового утворення автор спирався на грунтовні наукові напрацювання, здійснені останнім часом у межах наук теорії держави і права та конституційного права, зокрема на дослідження таких авторів, як С.І. Архіпов, М.В. Вітрук, Л.Д. Воєводін, Б.С. Ебзєєв, О.О. Кутафін, А.В. Міцкевич, А.В. Панчишин, А.В. Слепньов, В.Є. Чиркін та ін. У цих дослідженнях проблематика правового статусу розкривається в діалектиці взаємин держави та особистості, що має особливе значення в розрізі дослідження питань модернізації інституту юридичної відповідальності держави.

Водночас системне дослідження специфіки юридичної відповідальності як невід'ємного елемента правового статусу Української держави у вітчизняній загальнотеоретичній юриспруденції та конституціоналістиці відсутнє.

Мета та завдання дослідження. Основні цілі статті полягають у загальнотеоретичному та конституційно-правовому осмисленні ключових особливостей юридичної відповідальності як елемента правового статусу держави.

Виклад основного матеріалу. Поняття правового статусу є одним із визначальних та широко вживаних як у загальній теорії права, так і в межах галузевих правових наук. У науковій літературі слушно наголошується на багатоаспектності та внутрішній складності правового феномену, що охоплюється поняттям «правовий статус». Не заглиблюючись у деталі, можна навести основні підходи, що, на наш погляд, вдало відображають таку поліаспектність та структурованість правового статусу: система законодавчо встановлених і гарантованих державою прав, свобод, законних інтересів і обов'язків суб'єкта суспільних відносин [3, с. 366]; комплексна інтеграційна категорія, що відображає взаємовідносини суб'єктів суспільних відносин, особи і суспільства, громадянина і держави, індивіда та колективу, інші соціальні зв’язки [4, с. 184]; багатоаспектна категорія, що, по-перше, має загальний універсальний характер, включає різні статуси суб'єктів правовідносин (держави, суспільства, особи тощо); по-друге, відображає індивідуальні особливості суб’єктів і їх реальне становище в системі багатоманітних суспільних відносин; по-трете, правовий статус не може бути реалізований без обов'язків, що кореспондуються правам, без юридичної відповідальності та без гарантій; по-четверте, ця категорія визначає права та обов'язки суб'єктів права в системному вигляді, що дає змогу порівнювати правовий статус різних суб'єктів права для відкриття нових шляхів їх удосконалення [5, с. 549]; багатоаспектна, комплексна, універсальна категорія, що має чітку стабільну структуру та встановлює характер і принципи вза- 
ємодії суб'єктів суспільних відносин між собою, а також шляхом визначення прав, обов'язків та гарантій їх реалізації, визначає місце суб'єкта в системі правовідносин [6]; юридично закріплене становище суб'єкта в суспільстві, яке виражається в певному комплексі його прав та обов'язків; відображає юридично оформлені взаємовідносини особистості і суспільства, громадянина і держави, окремого індивіду з іншими; у ньому відображаються легальні межі свободи особи, обсяг її прав, обов’язків, інших правових можливостей і відповідальності [7].

Залежно від розуміння обсягу поняття правового статусу розрізняються і дещо різні підходи до тлумачення ролі та місця юридичної відповідальності в структуpi правового статусу: якщо більшість учених розглядає ії як елемент правового статусу, то дещо менша група дослідників відносить юридичну відповідальність до числа післястатусних елементів, поряд із гарантіями, законними інтересами тощо [8; 9].

Утім, на наш погляд, віднесення юридичної відповідальності до постстатусних елементів правового статусу, з одного боку, невиправдано протиставляє відповідальність правам та обов’язкам суб'єкта права, «розриває» їх змістовний та функціональний зв'язки, а, з іншого боку, занадто ускладнює розуміння самого правового статусу, виводячи із його структури істотні конструктивні елементи, що сполучають права та обов'язки (відповідальність). Саме тому ми вважаємо за можливе приєднатися до позиції тих дослідників, які розглядають юридичну відповідальність узагалі як невід’ємний елемент правового статусу суб'єкта права, безвідносно до специфіки такого суб’єкта (індивідуального чи колективного).

Утім, усе ж дещо модифікується розуміння співвідношення правового статусу та юридичної відповідальності й залежно від специфіки суб'єкта права, зокрема в розрізі підходу до держави як спеціального суб'єкта права, а також від того, який інваріант правового статусу слід розглядати по відношенню до держави. Так, нагадаємо, що в юридичній літературі набула поширення концепція «матрьошки правового статусу», суть якої зводиться до розрізнення загального, спеціального та індивідуального правових статусів суб'єкта права [6, с. 97; 10, с. 296-304; 11]. Якщо перший відображає правове становище абстрактних суб'єктів права одного роду (типу), що виражається в їхніх правах та обов'язках, переважно врегульованих конституційними нормами, то спеціальний правовий статус відображає правове становище абстрактних суб'єктів права одного виду всередині роди (типу), що переважно регулюються галузевими правовими нормами. Нарешті, індивідуальний правовий статус вказує на неповторні ознаки конкретного суб'єкта права і часто регулюється норами різних галузей права, становлячи міжгалузевий правовий інститут у межах національної системи права. Так, виокремлюють конституційно-правовий статус, цивільно-правовий статус, міжнародно-правовий статус держави тощо.

Інший підхід грунтується на виокремленні правового, конституційного та конституційно-правового статусів, що є вагомим у розрізі: а) суб'єкта конституційного права, яким є держава; б) співвідношення різних правових масивів, які стосуються виокремлення такого елемента цих статусів, як юридична, конституційна та конституційно-правова відповідальність держави. Якщо правовий статус i, відповід- 
но, юридична відповідальність держави характеризується найбільшою широтою параметрів та закріпленням у нормах різних галузей права, то конституційна відповідальність держави вичерпується нормами, вміщеними лише в конституції, а конституційно-правова відповідальність - у нормах, уміщених в усіх джерелах конституційного права як галузі національного права. При цьому, на думку Н.О. Богданової, конституційно-правовий статус включає в себе такі елементи: місце суб'єкта в суспільстві й державі, його соціально-політичну роль та призначення; загальну правоздатність; права і обов'язки (компетенцію) суб'єкта та відповідальність; гарантії сталості та реальності правового становища суб'єкта [12, с. 5].

У науці конституційного права сформувалася думка про своєрідний дуалізм правового статусу держави як специфічного об'єкта правового регулювання. 3 одного боку, йдеться про те, що держава - це форма політичного буття народу (субстантивний підхід), а з іншого - система органів (інституційний підхід), що спонукає вдаватися і до відповідної класифікації правових норм, які опосередковують правове буття держави [13, с. 219]. Найбільш придатним для застосування під час дослідження правового статусу держави видається саме інституційний підхід, який дає змогу не лише простежити діалектику «держава - державний апарат - орган державної влади», але і з'ясувати похідний характер юридичної відповідальності державного органу від юридичної відповідальності держави на основі концепції субсидіарної відповідальності держави, сформульованої ще С.О. Котляревським, М.I. Лазаревським, I.В. Михайло-вським, М. Оріу, В. Орландо, О.А. Флейшиц та іншими вченими наприкінці XIX - у першій половині XX ст. Адже саме утвердження цієї концепції знаменувало собою, за висловом I.В. Михайловського, вирішення «знаменитого питання про відповідальність держави за дії своїх посадових осіб» [14, с. 504-505].

Компліментарною до цих думок видається позиція, за якою саме держава володіє унікальною здатністю власноруч формувати свій правовий статус, як, зрештою, і правові статуси всіх інших суб'єктів правовідносин. 3 урахуванням галузевої специфіки, відтак, можна говорити про конституційно-правовий, цивільно-правовий та інші галузеві правові статуси держави як такої, які, втім, перебувають у певній системній єдності і можуть бути виокремлені лише умовно [15, с. 8].

Нарешті, в розрізі правосуб'єктності специфіка правового статусу держави грунтується на тому, що правосуб'єктність держави взагалі формується з функціональної правоздатності та дієздатності, яку держава набуває через чинний механізм здійснення державної влади. При цьому дієздатність держави починає складатися з моменту формування їі органів, що реалізують державні функції, а відсутня в держави фактична дієздатність заповнюється дієздатністю фізичних осіб, які перебувають на державній службі. Відтак держава консолідує дієздатність своїх службовців і набуває дієздатність в юридичному сенсі [16, с. 98-137]. Вищенаведені наукові позиції далеко не вичерпують найзагальніших уявлень щодо специфіки правового статусу держави в сучасному конституційному вимірі і мають значну палітру спірних позицій.

Доволі продуктивною, як на наш погляд, є застосовувана в юридичній науці концепція розгляду правового статусу держави через призму співставлення її як суб’єкта права із статусом юридичних осіб, зокрема з огляду на сконструйований, 
«штучний» характер як держави, так і юридичних осіб. Так, В.С. Чиркін, порівнюючи юридичних осіб публічного права з юридичними особами приватного права, до найбільш загальних ознак поняття юридичної особи публічного права відніс такі: 1) юридична особа публічного права - це завжди не приватно-правове, а публічно-правове утворення; 2) юридична особа публічного права має інше (в порівнянні з юридичною особою приватного права) соціальне призначення; 3) юридичні особи приватного та публічного права мають різні інтереси та волю; 4) юридична особа публічного права завжди пов'язана з публічною владою; 5) специфічні способи утворення юридичних осіб публічного права; 6) юридична особа публічного права має інший суб'єктний, матеріальний склад; 7) юридична особа публічного права має свою систему органів; 8) юридичні особи публічного права мають певну автономію у своїй діяльності; 9) відповідальність юридичних осіб публічного права у своїй основі має не приватноправовий, а публічно-правовий характер [17, с. 76-94]. Плідність такого підходу підкреслюється тим, що й досі деякі вчені обгрунтовують доцільність віднесення держави до числа особливих юридичних осіб [18; 19, с. 48], а у Швеції держава прямо названа юридичною особою [20].

Розглядаючи під таким кутом зору правовий статус держави, можна дійти висновків, що вона: 1) є публічно-правовим утворенням; 2) має власне соціальне призначення, відмінне від інших організацій, створюваних у суспільстві; 3) має власні інтереси та волю; 4) пов'язана зі здійсненням публічної влади; 5) має певний суб'єктний склад (державний апарат); 6) є продуктом народного волевиявлення, оскільки народ взагалі є джерелом державної влади; 7) має систему органів державної влади; 8) володіє суверенітетом як усередині країни, так і за їі межами; 9) її відповідальність має публічно-правовий характер. За такого підходу, зокрема, юридична відповідальність держави: 1) зумовлюється специфікою правового статусу держави; 2) відрізняється від юридичної відповідальності будь-яких інших фізичних та юридичних осіб; 3) має специфічні цільову та функціональну спрямованість; 4) володіє ознаками, які поєднують автономну та чужу волю (встановлюється самою державою всередині країни та узгоджується з іншими державами у міжнародних відносинах). Поряд із цим в юридичній літературі обгрунтовано думку, що «держава, як і будь-яка організація, набуває правовий статус юридичної особи лише за наявності певних ознак. Як зазначає переважна частина науковців, до ознак юридичної особи відносяться: 1) організаційна єдність; 2) майнова відокремленість; 3) здатність виступати у цивільному обігу від власного імені; 4) здатність нести самостійну майнову відповідальність; 5) здатність бути позивачем або відповідачем у суді» [21, с. 109-111]. Відповідно, ідентичними ознаками в цілому володіє держава, відрізняючись від згаданих юридичних осіб суб'єктом свого створення - оскільки джерелом влади є народ, то і установча влада зі створення держави належить саме йому. Слушною також видається позиція О.В. Пінаєвої, яка аналізує специфіку правового статусу держави через призму взаємовідносин із особистістю. Зокрема, на її погляд, держава вступає у відносини з особою як єдине ціле, так і за допомогою своїх органів; компетенція держави в таких відносинах установлюється самою державою; держава застосовує примус за порушення законів як до особи, так і до себе тощо [15, с. 10]. 
На доктринальному рівні зазвичай розглядають такі основні елементи правового статусу держави, як: ïï соціально-політична роль і призначення, її правосуб'єктність, компетенція і відповідальність або ж - більш компактно - цілі, права, обов’язки і відповідальність держави [22, с. 59-63; 13, с. 174]. Як видно, в обох варіантах йдеться про юридичну відповідальність як однин із конструктивних елементів правового статусу держави. Відповідно, у контексті конституційно-правового статусу держави йтиметься про конституційно-правову відповідальність, а стосовно конституційного статусу - про конституційну відповідальність держави. Звісно, що найсуттєвіші риси юридичної відповідальності держави набувають значення конституційних (конституційно-правових) і втілюються у відповідних правових нормах галузевого (конституційно-правового) характеру. В юридичній літературі, відповідно, розглядається юридична відповідальність як один із чільних елементів правового статусу держави, її органу тощо.

Разом із тим у силу специфіки свого правового статусу сама держава встановлює певні особливості своєї юридичної відповідальності: 1) вона встановлює певні правові бар'єри щодо виключення деліктоздатності в певних сферах, зокрема у кримінально-правовій, адміністративній та дисциплінарній; 2) матеріальна деліктоздатність держави в цілому аналогічна деліктоздатності юридичних осіб з урахуванням обмежень, установлених фінансовим і процесуальним законодавством у частині виконання судових рішень; 3) на відміну від фізичних та юридичних осіб, саме держава володіє міжнародно-правовою та конституційно-правовою деліктоздатністю [20]. При цьому публічно-правові заходи, як засіб притягнення до відповідальності, можуть застосовуватись до держави за невиконання або виконання неналежним чином її обов' язків, а так само обов'язків її органів. 3 огляду на те, що в міжнародному та в конституційному праві уособленням держави в конкретних правовідносинах виступають державні органи, наділені відповідною компетенцією, то відповідно до концепції субсидіарної юридичної відповідальності за їхні дії відповідальність несе саме держава. При цьому лише в конституційній субсидіарній відповідальності держава як відповідач має понести відповідальність незалежно від бажання її прийняти [23, с. 118].

3 теоретико-правового боку важливо наголосити також на тому, що юридична відповідальність держави є динамічним елементом їі правового статусу, який здебільшого розглядається як у цілому статична правова конструкція. Проте юридична відповідальність, образно кажучи, «приводить у рух» обов'язки держави перед суспільством, особою, іншими державами, перед нинішнім і прийдешніми поколіннями, титульною нацією тощо, гарантуючи здійснення цих обов'язків. У такий спосіб пріоритетними функціями юридичної відповідальності держави в позитивному аспекті виступає превентивна та гарантувальна. Адже, як зауважують дослідники, важливим є розуміння того, що нині «держава - це не тільки і не стільки суб'єкт політики, скільки носій прав, юридичних обов'язків і суб'єкт юридичної відповідальності, тобто суб'єкт права» [24]. Із означеного доктринального розуміння випливає, зокрема, той факт, що правовий статус держав, насамперед, опосередковує права та обов'язки її як суб'єкта права в системній єдності із юридичною відповідальністю такої держави, що зумовлюється певним набором 
наявних у неї прав та обов'язків. За такого підходу юридична відповідальність держави не лише вписується у правовий статус держави як суб'єкта права, але і зумовлюється осердям цього правового статусу, тобто набором, конкретною специфікою, широтою та співвідношенням наявних у держави прав та обов'язків, що релевантні широті конституційних прав людини і громадянина, визнавати, утверджувати і захищати які покликана держава, як ціле, і ї̈ органи, як спеціально уповноважені державою особи.

Водночас такі права та обов'язки (а отже і відповідальність) держави реалізуються в системі правових зв'язків з іншими суб'єктами права, насамперед, з іншими державам, громадянами своєї та інших держав, юридичними особами, утвореними відповідно до законодавства держави, органами державної влади тощо. Складна система суб’єктів конкретних правовідносин та наявність у держави певних прав і обов'язків перед ними зумовлює багатоманітність палітри юридичної відповідальності держави як змістовного елемента її правового статусу у спілкуванні з відповідними суб’єктами права.

Досліджуючи специфіку юридичної відповідальності держави у структурі їі правового статусу, також варто підтримати позицію щодо двохаспектної відповідальності держави: позитивної та негативної, адже такий підхід дозволяє визначити механізм відповідальності державної влади перед народом, суспільством, людиною і громадянином, зрозуміти місце і роль конкретної держави у сучасному цивілізаційному розвиткові, зробити її відповідальною за те, що відбувається не лише в моральному, але і в юридичному сенсі відповідальності перед нинішніми і прийдешніми поколіннями [22]. Утім, двохаспектність юридичної відповідальності держави може бути простежена в контексті дослідження правового статусу і в тому, що така відповідальність може інтерпретуватися в сенсі: 1) загального правовідношення (правового стану), що позначає собою постійні, тривалі правові зв'язки між державою та іншими суб'єктами права, що полягають у виконанні державою взятих на себе обов'язків та позитивних зобов'язань (у контексті концепції affirmative obligations [25]); 2) конкретних правовідносин із зазнавання державою певних несприятливих наслідків за невиконання взятих на себе обов'язків і зобов'язань.

Зауважимо також на факті, що у сучасній юриспруденції чимала низка учених зосередила увагу на проблемах розвитку та модернізації комплексного інституту юридичної відповідальності з урахуванням потреб правового розвитку, правової реформи в країні тощо. У зв'язку із цим виокремлені ті чи інші ключові та перспективні тренди розвитку означеного інституту [26; 27]. Проте вони часом слабко релевантні сучасному етапові розвитку держави та тенденціям модернізації власне їі відповідальності у правовому вимірі.

За нинішніх умов держава визначається «сучасною» в юридичній та політологічній літературі за різними якісними параметрами. Характерно, що в загальнотеоретичній юриспруденції та в конституційно-правовій науці зокрема найчастіше йдеться про взаємовиключні, на перший, погляд, тенденції до розширення компетенції держав (надмірна юридизація, навіть етатизація суспільного життя), що позначає розширення меж державного втручання у суспільні та індивідуальні спра- 
ви, а з іншого боку - про делегування державою значного кола своїх повноважень інститутам громадянського суспільства [28, с. 149-162], місцевого самоврядування, міжнародним і наднаціональним організаціям [29, с. 82] тощо. Зрештою, у розвиткові різних держав на сучасних етапах можна простежити присутність кожної з означених макротенденцій. Значимим у контексті нашого дослідження є те, що такі тенденції значно модифікують правовий статус держави. Зокрема, осмислення відповідних процесів зумовлює появу тверджень про занепад національної держави [30], перетворення держав на сервісні [31, с. 163-174], про віртуалізацію держави [32] тощо.

Так, описуючи сучасну державу, М.В. Разуваєв звергає увагу на те, що вона: 1) передбачає певне соціальне середовище у вигляді розвинутих інститутів громадянського суспільства; 2) виступає від імені всіх громадян, здійснюючи діяльність, скеровану на вирішення «спільних справ»; 3) є не лише демократичною і правовою, але також і соціальною [33, с. 284]. Наголошується й на тому, що в сучасній державі «відбувається переорієнтація від ідей управління та керування до ідей служіння та керованості. Система прийняття владних рішень будується не стільки на ідеях жорсткої ієрархічності, скільки на основі мережевих систем із широкими не тільки вертикальними, але й горизонтальними зв'язками. При цьому до даної системи зараховуються недержавні організації громадського контролю, які мають реальну можливість впливу на сучасну державу. Якісно змінюється суб'єктний склад механізму, державними службовцями у сучасній державі покликані бути професійні менеджери, діяльність яких формується навколо ідей технократизму. Нетипово для «досучасних" держав вона починає вступати у взаємодію із приватним сектором, при цьому "основою такої кооперації виявляються виключно договірні форми» [34, с. 16]. На нашу думку, навіть делегуючи частину своєї компетенціїіншим суб'єктам права, держава не звільняється від відповідальності за виконання цієї частини загальносуспільних справ. Так, наприклад, відповідно до ч. 3 ст. 143 Конституції України органам місцевого самоврядування можуть надаватись окремі повноваження органів виконавчої влади [35]. Натомість в українському законодавстві відсутня відповідальність держави за неналежне фінансування делегованих повноважень органам місцевого самоврядування, що нівелює систему правових гарантій місцевого самоврядування, порушує принцип субсидіарності та солідарності.

Поширення концептів сервісної та електронної держави, переведення багатьох публічних послуг в електронний вимір порушує питання унеможливлення ексцесів замахів та стороннього ураження відповідних електронних баз даних із боку зловмисників. Відповідно, держава має взяти на себе тягар гарантування непорушності прав людини у зв’язку із діджиталізацією багатьох сфер державного управління. Так само розширення каталогу прав людини, поява так званого четвертого покоління прав людини [36, с. 141-144] не може не призвести до розширення меж як позитивної, так і негативної відповідальності держави у сфері їх гарантування. Насамкінець пригадаємо, що об’єктивно збільшення «питомої ваги» юридичної відповідальності держави зумовлюється і принциповою зміною стратегічного курсу Української держави у зв'язку з конституційно закріпленими зобов'язаннями з інтеграції України до Європейського Союзу, про що ми вже писали раніше [37]. 
Висновки. Юридична відповідальність держави стає органічною частиною політико-правового дискурсу на сучасному етапі розвитку Української держави. Проблематика юридичної відповідальності щільно вмонтовується у феномен правового статусу держави, у структурі якого вона виступає в ролі невід'ємного складового елемента. Розвиток інституту юридичної відповідальності держави відображає як загальні закономірності розвитку правового статусу держави, так і особливості еволюції її елементів, зокрема повноважень держави. Водночас юридична відповідальність держави виступає як гарантією належної реалізації повноважень держави в різних сферах суспільних відносин, так і гарантією належного утвердження, забезпечення і захисту прав її громадян. За сучасних умов з урахуванням новітніх тенденцій конституційного розвитку стрімко розгортається тенденція розширення сфери юридичної відповідальності держави, синхронізована з еволюцією прав людини, необхідністю зміцнення правових гарантій їх здійснення тощо. Виклики, 3 якими стикається сучасна держава, модернізація її правового статусу, наближення України до європейської цивілізації зумовлюють подальше суттєве зростання юридичної відповідальності держави, що має бути закріплено як на рівні позитивного права, так і в повсякденних практиках державного владарювання.

\section{Jimepamypa}

1. Середюк В.В. Відповідальність держави як елемент поняття «правова держава». Часопис Київського університету права. 2015. № 1. С. 41-45.

2. Шемшученко Ю.С., Скрипнюк О.В., Ющик О.І., Антонов В.О., Костецька Т.А., Куян I.А., Мурашин Г.О., Суржинський М.I. Проблеми розвитку конституційного права України на сучасному етапі : теорія і практика. Правова держава. 2014. Вип. 25. С. 66-97.

3. Теорія держави і права : Академічний курс / за ред. В.О. Зайчука, Н.М. Оніщенко. Київ : Юрінком Інтер, 2008. $400 \mathrm{c.}$

4. Малько А.В. Матузов Н.И. Теория государства и права. Москва : Юрист, 2001. 776 с.

5. Корельский В.М., Перевалов В.Д. Теория государства и права. 2-е изд., изм. и доп. Москва : ИНФРА-М, НОРМА, $2002.616 \mathrm{c.}$

6. Панчишин А.В. Поняття, ознаки та структура категорії «правовий статус». Часопис Київського університету права. 2010. № 2. С. 95-98.

7. Большой юридический словарь / под ред. А.В. Малько. Москва, 2009. 704 с.

8. Права человека : учебник для вузов / отв. ред. Е.А. Лукашева. Москва, 1999. 573 с.

9. Михнева С.В. Правовой статус муниципального служащего в России : Нижневолжский регион : дисс. ... канд. юрид. наук : 12.00 .02 . Волгоград, 2003. 223 с.

10. Витрук Н.В. Общая теория правового положения личности. Москва : НОРМА, 2008. 448 с.

11. Левченко И.П., Облиенко С.В. Индивидуальный социально-правовой статус личности : монография. Москва : Книжный мир, МосУ МВД РФ, 2005. 81 с.

12. Богданова Н.А. Категория статуса в конституционном праве. Вестник Московского университета. Серия 11. Право. 1998. № 3. С. 3-20.

13. Шустров Д.Г. Приручённый Левиафан : государство как объект конституционно-правового регулирования. Санкт-Петербург : Издательский Дом «Алеф Пресс», 2014. 432 с.

14. Михайловский И.В. Очерки философии права. Т. 1. Томск : В.М. Посохин, 1914.632 с.

15. Пинаева О.В. Государство как субъект правоотношения в современном обществе : автореф. дисс. ... канд. юрид. наук : 12.00.01. Ярославль, 2008. 165 с.

16. Слепнев А.В. Государство как субъект правоотношений : дисс. ... канд. юрид. наук : 12.00.01. Москва, 2009. $243 \mathrm{c.}$

17. Чиркин В.Е. Юридическое лицо публичного права. Москва : Норма, 2007. 352 с.

18. Комягин Д.Л. Правовые механизмы недопущения роста задолженности бюджета. Право и экономика. 2000. № 5. С. $26-29$. 
19. Лукашук И.И. К вопросу о возможной криминализации международной ответственности государств. Журнал российского права. 2002. № 12. 107-119.

20. Гарипов Р.Ф. Деликтоспособность как правовая категория: монография / под ред. О.И. Зазнаева. Казань : Редакционно-издательский центр, 2011. 144 с.

21. Цивільне право України : підручник у 2-х кн. Кн. 1. О.В. Дзера (керівник авт. колективу), Д.В. Боброва, А.С. Довгерт та ін. ; за ред. О.В. Дзери, Н.С. Кузнєцової. Київ : Юрінком Інтер, 2002.719 c.

22. Бутусова Н.В. Конституционно-правовой статус российского государства : монография. Москва : Изд-во Моск. ун-та; Воронеж : Изд-во Воронеж. гос. ун-та, 2006. 376 с.

23. Сельська В.В. Субсидіарна юридична відповідальність: загальнотеоретичне дослідження : автореф. дис. ... канд. юрид. наук : 12.00.01. Одеса, 2019. 24 с.

24. Мусатов Ф.В. Государство как субъект права : дисс. ... канд. юрид. наук : 12.00.01. Екатеринбург, 2016. 231 с.

25. Христова Г.О. Доктрина позитивних зобов’язань держави у сфері прав людини : дис. ... докт. юрид. наук : 12.00.01. Харків, 2019. 512 с.

26. Терещук М.М. Юридична відповідальність у публічному праві : автореф. дис. ... канд. юрид. наук : 12.00.01. Київ, 2019. 22 с.

27. Калєніченко Л.І. Юридична відповідальність як форма державно-правового примусу : загальнотеоретична характеристика : автореф. дис. докт. юрид. наук : 12.00.01. Харків,2018. 42 с.

28. Григорьева В.А. Конституционно-правовое положение государства в российской экономической системе : дисс. ... канд. юрид. наук : 12.00.02. Москва, 2014. 259 с.

29. Василевич Г.А., Василевич Д.Г. Народ и государство как важнейшие субъекты конституционно-правовых отношений. Весник БДУ. Сер. 3. 2015. № 2. С. 81-84.

30. Серебро М.В. Сучасна та національна держава : концептуальні основи та перспективи. Науковий вісник Ужгородського національного університету. Серія : Право. 2016. № 36. С. 10-15.

31. Дзевелюк М.В. Традиції та новації в розвитку функцій сучасної держави : дис. ... канд. юрид. наук : 12.00.01. Одеса, 2017. 209 с.

32. Потерейко 0.О. Віртуалізація держави : теоретико-методологічний аналіз : дис. ... канд. політ. наук 23.00.01. Львів, 2019. 219 с.

33. Разуваев Н.В. Эволюция государства : социально-антропологический и юридический аспекты : дисс. ... докт. юрид. наук : 12.00.01. Санкт-Петербург, 2016. С. 284.

34. Серебро М.В. Сучасна держава як цінність : загальнотеоретичне дослідження : автореф. дис. ... канд. юрид. наук : 12.00.01. Одеса, 2017. 24 с.

35. Конституція України : Закон України від 28 червня 1996 року. URL : https://zakon.rada.gov.ua/ laws/show $/ 254 \kappa / 96$-вр.

36. Савчин М. Порівняльне конституційне право : навч. посіб. Київ : Юрінком Інтер, 2019. 328 с.

37. Бакумов О.С. Конституціоналізація стратегічного курсу України в контексті доктрини юридичної відповідальності держави. Право і Безпека. 2018. № 4. C. 13-21. URL : http://nbuv.gov.ua/ UJRN/Pib_2018_4_3. 


\section{Анотація}

Бакумов О. С. Юридична відповідальність як елемент правового статусу держави: теоретикоправові аспекти. - Стаття.

У статті показано, що юридична відповідальність держави стає органічної частиною політико-правового дискурсу на сучасному етапі розвитку Української держави. Доведено, що проблематика юридичної відповідальності щільно вмонтовується у феномен правового статусу держави, у структурі якого вона виступає в ролі невід'ємного складового елемента. Обгрунтовано, що розвиток інституту юридичної відповідальності держави відображає як загальні закономірності розвитку правового статусу держави, так і особливості еволюції її елементів, зокрема повноважень держави. Виявлено, що юридична відповідальність держави виступає і як гарантія належної реалізації повноважень держави в різних сферах суспільних відносин, і як гарантія належного утвердження, забезпечення і захисту прав її громадян. Акцентовано на тому, що виклики, з якими стикається сучасна держава, модернізація її правового статусу, наближення України до європейської цивілізації зумовлюють подальше суттєве зростання юридичної відповідальності держави, що має бути закріплено як на рівні позитивного права, так і в повсякденних практиках державного владарювання.

Наголошено, що особливостями юридичної відповідальності держави є: 1) вона встановлює певні правові бар'єри щодо виключення деліктоздатності в певних сферах, зокрема у кримінально-правовій, адміністративній та дисциплінарній; 2) матеріальна деліктоздатність держави у цілому аналогічна деліктоздатності юридичних осіб з урахуванням обмежень, установлених фінансовим і процесуальним законодавством у частині виконання судових рішень; 3) на відміну від фізичних та юридичних осіб, саме держава володіє міжнародно-правовою та конституційно-правовою деліктоздатністю. Визначено, що на підставі аналізу правового статусу державу можливо характеризувати таким чином: 1) $\epsilon$ публічно-правовим утворенням; 2) має власне соціальне призначення, відмінне від інших організацій, створюваних у суспільстві; 3) має власні інтереси та волю; 4) пов'язана зі здійсненням публічної влади; 5) має певний суб'єктний склад (державний апарат); 6) є продуктом народного волевиявлення, оскільки народ взагалі є джерелом державної влади; 7) має систему органів державної влади; 8) володіє суверенітетом як усередині країни, так і за її межами; 9) її відповідальність має публічно-правовий характер.

Ключові слова: держава, публічне утворення, юридична відповідальність держави, правовий статус, Конституція України.

\section{Summary}

Bakumov O. S. Legal responsibility as an element of the legal status of the state: theoretical and legal aspects. - Article.

The article shows that the legal responsibility of the state becomes an organic part of the political and legal discourse at the present stage of development of the Ukrainian state. It is proved that the problem of legal liability is firmly embedded in the phenomenon of the legal status of the state, in the structure of which it acts as an integral component. It is substantiated that the development of the institute of legal responsibility of the state reflects both the general regularities of the development of the legal status of the state and the peculiarities of the evolution of its elements, in particular the powers of the state. It is revealed that the legal responsibility of the state acts as a guarantee of the proper exercise of the state's powers in various spheres of public relations, as well as a guarantee of the proper assertion, protection and protection of the rights of its citizens. It is emphasized that the challenges faced by the modern state, the modernization of its legal status, and the approximation of Ukraine to European civilization lead to a further substantial increase in the legal responsibility of the state, which should be enshrined both at the level of positive law and in the everyday practices of state power process.

It is emphasized that the peculiarities of the legal responsibility of the state are: 1) it establishes certain legal barriers to exclusion of tort in certain areas, in particular in criminal, administrative and disciplinary; 2) the material tort of the state as a whole is similar to the tort of legal entities, taking into account the restrictions set by the financial and procedural legislation in terms of enforcement of court decisions; 3) unlike individuals and legal entities, the state itself has international legal and constitutional legal tort. It is determined that on the basis of the analysis of the legal status the state can be characterized as follows: 1) is a public-legal entity; 2) has its own social purpose, different from other organizations established in society; 3) has its own interests and will; 4) related to the exercise of public authority; 5) has a certain subject composition (state apparatus); 6 ) is a product of popular expression, since the people are generally a source of state power; 7) has a system of public authorities; 8) has sovereignty both domestically and abroad; 9) her responsibility is public and legal

Key words: state, public body, legal responsibility of the state, legal status, Constitution of Ukraine. 